\title{
IDENTIFICATION OF THE QUALITY OF COFFEE BEANS SUBJECTED TO DIFFERENT DRYING PROCESSES
}

\section{Matheus C. de Almeida*, Juliana A. Fracarolli, Juliana C. do Prado, Gerson S. Giomo.}

\section{Abstract}

The method of drying coffee beans is one of the many factors that can interfere with their physical and chemical integrity, attributing quality and value to the product. Thus, this research aimed to evaluate, based on electrical conductivity and leaching of potassium tests, which one of the drying methods used for the Red Catuaí IAC 99 variety are shown to be less harmful to the cell membrane of the beans. Although the research still has tests in progress, it is possible to conclude that coffee pulped was the process that showed the least damage to the bean membrane.

\section{Key words:}

Coffea arabica,leaching of potassium, electrical conductivity.

\section{Introduction}

Coffee is one of the most consumed and valued beverages in the world and has great historical, economic and social importance in Brazil, being the country the largest producer and exporter in the world.

Thus, producing a quality grain is a fundamental requirement for the beverage to have the aspects of aroma and flavor desired by consumers. One of the factors that can affect quality is the drying method applied to the product.

One of the ways to evaluate the influence of the drying method on the characteristics of the grain is by observing the integrality of its cell membrane, using tests of electrical conductivity and leaching of potassium and sensory analysis.

Thus, the present research aims to evaluate, based on these tests, which of the drying methods used for the Red Catuaí IAC 99 variety are shown to be less harmful to the bean cell membranes and consequently adhere to higher quality coffee.

\section{Results and Discussion}

After processing and drying, the treatments were packaged in aluminized packaging and stored in a cold room. The first sample was after the drying process, proceeding with the electrical conductivity and leaching of potassium analysis (table 1 ), the $2^{\text {nd }}$ was performed in the $4^{\text {th }}$ month (table 2 ) and the $3^{\text {rd }}$ is in progress.

Table 1 - Results for electrical conductivity and leaching of potassium - $1^{\text {st }}$ sampling.

\begin{tabular}{|c|c|c|c|}
\hline \multicolumn{2}{|c|}{ Eletric Conductivity } & \multicolumn{2}{|c|}{ Leaching of potassium } \\
\hline Treatment ${ }^{\star}$ & $\begin{array}{c}\text { Value } \\
\left(\mu \mathrm{S} / \mathrm{cm}^{*} \mathrm{~g}\right)^{* *}\end{array}$ & Treatment ${ }^{\star}$ & $\begin{array}{c}\text { Value } \\
(\mathrm{mg} / \mathrm{Kg})^{\star *}\end{array}$ \\
\hline CDC & $83,44 \quad a$ & CNC & $90,29 \quad$ a \\
\hline T5 & $96,68 \quad a b$ & CDC & $121,72 \mathrm{ab}$ \\
\hline BS & $109,94 \mathrm{bc}$ & $B C$ & $181,16 \mathrm{bc}$ \\
\hline$B C$ & $111,21 \mathrm{bc}$ & T5 & $239,62 \mathrm{c}$ \\
\hline CNC & 119,62 bc & CDS & $247,50 \mathrm{c}$ \\
\hline CNS & $124,71 \mathrm{c}$ & BS & $351,35 \mathrm{~d}$ \\
\hline CDS & $127,59 \mathrm{c}$ & CNS & $378,86 \mathrm{~d}$ \\
\hline CV\% ${ }^{* \star *}$ & 21,35 & CV\% ${ }^{* * *}$ & 34,70 \\
\hline
\end{tabular}

Table 2 - Results for electrical conductivity and leaching of potassium $-2^{\text {nd }}$ sampling.

\begin{tabular}{|c|c|c|c|}
\hline \multicolumn{2}{|c|}{ Eletric Conductivity } & \multicolumn{2}{|c|}{ Leaching of potassium } \\
\hline Treatment ${ }^{\star}$ & $\begin{array}{c}\text { Value } \\
\left(\mu \mathrm{S} / \mathrm{cm}^{*} \mathrm{~g}\right)^{* *}\end{array}$ & Treatment ${ }^{\star}$ & $\begin{array}{c}\text { Value } \\
(\mathrm{mg} / \mathrm{Kg})^{\star \star}\end{array}$ \\
\hline CDS & $82,22 \quad a$ & CDS & $189,31 \quad a$ \\
\hline CDC & 86,90 a & CDC & 197,72 a \\
\hline BS & $103,71 \mathrm{~b}$ & BS & 234,85 bc \\
\hline T5 & $109,53 \mathrm{~b}$ & $B C$ & $251,10 \mathrm{bc}$ \\
\hline$B C$ & $112,89 \mathrm{~b}$ & T5 & $257,28 \mathrm{c}$ \\
\hline CNS & $125,51 \mathrm{c}$ & CNS & $294,44 \mathrm{c}$ \\
\hline $\mathrm{CNC}$ & $129,71 \mathrm{c}$ & $\mathrm{CNC}$ & $297,59 \mathrm{c}$ \\
\hline $\mathrm{CV}^{* \text { ***}}$ & 8,91 & $\mathrm{CV}^{* \text { ***}}$ & 12,01 \\
\hline
\end{tabular}

* BS (Floater-dried in suspended patio); BC (Floater-dried in patio); T5 (Conventional); CDC (Coffee Pulped-dried in patio); CDS (Coffee Pulpeddried in suspended patio); CNC (Natural Cherry Coffee-died in patio); CNS (Cherry Coffee- dried in suspended patio).

** Averages followed by the same letter in the column do not differ significantly by the $5 \%$ Tukey test.

${ }^{* \star \star}$ Coefficient of Variation

From the results obtained, it is possible to observe that the values of electrical conductivity increased in the second sample, where the grains were stored for longer, which is confirmed by what Ribeiro (2013) observed. It is also observed that the highest values of electrical conductivity and leaching of potassium in the $2^{\text {nd }}$ sample were found in natural cherry coffees while the lowest were found in coffees pulped, characterizing the pulped as less harmful to the grain membranes. Therefore, the drying methods (drying on ground of patio and drying in suspended) did not differ from each other but from the fruit processing methods.

\section{Conclusions}

Although the research still has ongoing tests, it is possible to conclude that coffee pulped showed less damage to the membrane than natural cherry coffee.

\section{Acknowledgement}

I thank the guidance counselor Prof. Dr. Juliana A. Fracarolli for the opportunity and confidence and the cosupervisor Juliana C. do Prado for all the support provided throughout the development of the project. 